\title{
OxyContin was submitted and justifiably approved by the agency as a 12-hour dosage form
}

\author{
Jeffrey Fudin ${ }^{1,2}$ \\ Mena Raouf ${ }^{3}$ \\ Erica L Wegrzyn ${ }^{4}$ \\ 'REMITIGATE, LLC, ${ }^{2}$ Stratton Veteran \\ Affairs Medical Center, Albany, NY, \\ ${ }^{3}$ Veteran Affairs Tennessee Valley \\ Healthcare System, Alvin C York \\ Campus, Murfreesboro, TN, ${ }^{4}$ Stratton \\ Veteran Affairs Medical Center, \\ Albany, NY, USA
}

This article was published in the following Dove Press journal: Journal of Pain Research

7 September 2016

Number of times this article has been viewed

Extended-release (ER) or long-acting (LA) opioids are increasingly used for management of chronic pain. Approximately 3.8 million patients receive prescriptions for ER/ LA opioids in the US. ${ }^{1}$ The number of prescriptions dispensed for ER/LA has more than doubled over the past decade, increasing from 9.3 million in 2000 to 22.9 million in 2009. Consequently, in 2012, the US Food and Drug Administration (FDA) developed a risk evaluation and mitigation strategy for ER/LA opioids. ${ }^{2}$

Opioids are characterized by a high interindividual variability in response, which can also change in a given patient over time due to development of tolerance, progression of the underlying etiology, and age; therefore, opioids cannot be approached as "one size fits all", ${ }^{3,4}$ It is imperative to individualize therapy for each patient with careful monitoring and adjustments for safety and efficacy. The dosing intervals for ER formulations are established during clinical trials; however, in clinical practice, some patients may require more frequent dosing.

MS Contin (morphine sulfate ER), for example, is approved for every 12-hour dosing, but the manufacturer label addresses the fact that some patients may require dosing at 8-hour intervals. ${ }^{5}$ Similarly, fentanyl transdermal (TD Duragesic) is approved for every 72-hour dosing, whereas the labeling states "Some patients may not achieve adequate analgesia using this dosing interval and may require TD systems to be applied every 48 hours rather than every 72 hours". ${ }^{6}$ Unlike the aforementioned agents, OxyContin's FDA-approved labeling lists 12-hour dosing and does not address dosing at more frequent intervals. The label states "patients who experience breakthrough pain may require dosage adjustment or rescue medication". ${ }^{7}$

In a recent article "You Want a Description of Hell?", The LA Times implies that Purdue's claim on OxyContin (oxycodone controlled release) relieving pain for 12 hours led to some patients experiencing returning pain and agonizing withdrawal. ${ }^{8}$ The article stated "Purdue has known about the problem for decades. Even before OxyContin went on the market" and "the company has held fast to the claim of 12-hour relief, in part to protect its revenue". According to the code of federal regulations 202.1, pharmaceutical companies are prohibited from promoting off-label uses for medications or advertising statements to providers or patients that are not approved by the FDA. Due to this regulation, it is unlawful for Purdue Pharma to promote oxycodone controlled release (CR) for a dosing interval other than every 12 hours. The FDA cited a lack of clinical evidence that "prescribing OxyContin for dosing more frequently than $\mathrm{q} 12 \mathrm{~h}$ is associated with increased risk for adverse reactions", which reinforced the 12-hour dosing interval. ${ }^{9}$
Correspondence: Jeffrey Fudin REMITIGATE, LLC, 357 Delaware Avenue \#2 I4, Delmar, NY 12054, USA Email jeff@paindr.com 
In 2004, Connecticut's Attorney General Richard Blumenthal led a petition to revise oxycodone CR's black box warning to specifically warn against dosing more frequently than every 12 hours and send corresponding letters to health care providers. The petition proposed a revision stating "Dosing OxyContin at intervals of q 8 h or shorter may cause an increase in oxycodone plasma concentrations and thereby increase the risks of side effects such as euphoria and sedation. Proper dosing further minimizes the potential for abuse and diversion". ${ }^{10}$ The FDA denied the petition for lack of clinical evidence supporting the claims and requests, and Mr Blumenthal then sued the FDA. ${ }^{10,11}$

The efficacy and tolerability of opioids may differ significantly from one patient to another due to genetic variation, opioid receptor polymorphisms, pharmacokinetic differences, tolerance, and presence of comorbidities., ${ }^{3,12}$ There are important pharmacogenetic considerations with oxycodone that can affect response. Oxycodone is metabolized by cytochrome P450 (CYP) enzymes with CYP3A4 as the major pathway to noroxycodone (47\%) and by CYP2D6 to oxymorphone (11\%). ${ }^{7,13}$ Although the activity of oxycodone is primarily due to the parent drug, pharmacogenetic variations in enzyme activity or drug-drug interactions could play a role in its analgesic effect. For example, a poor CYP2D6 metabolizer could have less conversion to oxymorphone and experience lower analgesic effect. The same effect could be witnessed in a patient taking a concomitant CYP2D6 inhibitor, including antidepressants fluoxetine, paroxetine, or bupropion, where use may coincide in chronic pain patients.

Pharmacokinetic studies in normal volunteers demonstrated that immediate release (IR) oxycodone $5 \mathrm{mg}$ q6h and oxycodone controlled release $10 \mathrm{mg} \mathrm{q} 12 \mathrm{~h}$ had similar troughs of $7.4 \pm 3.8 \mathrm{ng} / \mathrm{mL}$ and $7.2 \pm 3.5 \mathrm{ng} / \mathrm{mL}$, respectively. ${ }^{14}$ The oxycodone controlled release $10 \mathrm{mg} \mathrm{q} 12 \mathrm{~h}$ regimen yielded a maximum plasma concentration of $15.1 \pm 4.7 \mathrm{ng} / \mathrm{mL}$. Theoretically, based on Figure 1, oxycodone controlled release $10 \mathrm{mg} \mathrm{q} 12 \mathrm{~h}$ regimen would provide $8-10$ hours above $50 \%$ maximum plasma concentration $\left(C_{\max }\right)$. In a multicenter survey of 660 cancer patients on oral sustained-acting opioids (MS Contin, oxycodone controlled release), patients reported average pain relief duration of 9.6 hours. ${ }^{15}$ This could be related to the decline in serum levels. However, it is important to note that a therapeutic range is not available for opioids due to variable tolerance, opioid receptor polymorphisms, pharmacogenetic differences, and presence of comorbidities. ${ }^{12}$

When administered every 12 hours, oxycodone controlled release demonstrated biphasic peaks and troughs within a 12-hour span and remained within the therapeutic range at

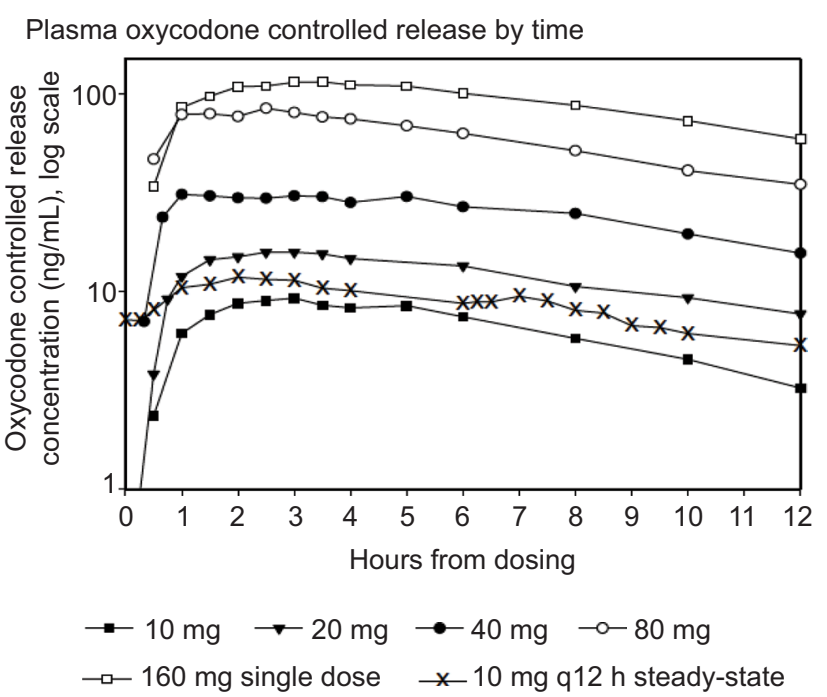

Figure I Oxycodone controlled release dose-based serum levels by time. ${ }^{14}$ Abbreviation: $\mathrm{q} / 2 \mathrm{~h}$, orally every 12 hours.

the sixth and 12th hours after a single dose. ${ }^{16}$ Comparatively, the IR liquid formulation required repetitive dosing twice as often to maintain blood levels within the therapeutic dosage range. The serum concentration at the end of the 12-hour dosing interval $\left(C_{\min }\right)$ for the oxycodone $\mathrm{CR}$ arm was $6.2 \pm 2.6$ compared to $6.5 \pm 3.1$ in the IR oxycodone arm. The authors concluded that both regimens yielded similar peaks, troughs, and serum fluctuations. This study demonstrates that oxycodone CR dosed every 12 hours provides similar exposure to the IR product dosed every 6 hours, but the $\mathrm{CR}$ formulation avoids a precipitous drop in serum concentrations at the sixth hour following a single dose at steady state. In conclusion, the oxycodone $\mathrm{CR}$ is well positioned to be dosed every 12 hours as initially demonstrated to and approved by the FDA in 1995. From a practical standpoint, if a patient presented on follow-up with end-of-dose failure measured by increased pain while maintained on oxycodone $\mathrm{CR}$, the clinician has two choices increase the dose and continue with 12-hour intervals or titrate using an 8-hour dosage interval, which may allow less overall drug exposure between doses. For example, a patient may be switched from oxycodone CR $40 \mathrm{mg}$ PO q12h (80 mg per day) to $30 \mathrm{mg}$ PO q8h ( $90 \mathrm{mg}$ per day), instead of raising the overall daily dose to $100 \mathrm{mg}$ per day by providing two separate prescriptions for $50 \mathrm{mg}(40 \mathrm{mg} \times$ one tablet plus $10 \mathrm{mg} \times$ one tablet) PO q12h. Alternatively, the regimen could be changed to $45 \mathrm{mg}$ ( $15 \mathrm{mg} \times$ three tablets) $\mathrm{PO}$ q $12 \mathrm{~h}$ for a $90 \mathrm{mg}$ per day dose, but this requires many more tablets and may increase the risk of diversion or tablet sharing.

According to oxycodone CR's FDA-approved label, "patients who experience breakthrough pain may require 
dosage adjustment or rescue medication". This translates to using higher doses at 12-hour intervals or supplementing with IR; however, when considering patient uniqueness, it is plausible that neither option is optimal. Raising the dose while maintaining a 12-hour interval will increase the area under the curve but will also result in increased serum fluctuations causing a greater difference between the peak and trough. Supplementing with IR oxycodone at scheduled intervals introduces additional peaks producing additional serum fluctuations. Instead, the optimal approach may be to administer one-third of the total daily dose every 8 hours. What are the drawbacks of peaks and troughs? High peaks are associated with doserelated adverse effects including sedation and potential lifethreatening respiratory depression, whereas low troughs are associated with rebound pain. ${ }^{17,18}$ Therefore, one benefit of CR opioids is to maintain constant blood levels by minimizing peaks and troughs exhibited by their IR opioid counterparts. There are certainly advantages to IR opioids, particularly the lesser effect on hypoadrenal axis. ${ }^{19,20}$ Notwithstanding, the side-effect profile, more restful sleep, and compliance are all generally superior for CR compared to IR. ${ }^{21-24}$

In a survey of 128 patients on stable doses of oxycodone CR for 6 months, clinicians evaluated the frequency of IR opioid use in patients on 12-hour and 8-hour dosing. ${ }^{25}$ The authors concluded that patients on 12-hour dosing were twice as likely to use scheduled IR opioids to achieve pain relief. This creates a series of breakthrough pain episodes and inadequately controlled pain on maintenance medication, potentially leading to pseudoaddiction. Pseudoaddiction is an iatrogenic phenomenon due to poorly controlled pain where patients become preoccupied with their next opioid dose. ${ }^{26}$ Such phenomenon could be averted by maintaining constant blood levels of the medication.

The war on opioids has created an unfortunate culture where often the focus is shifted toward political gains and flashy media coverage containing half-truths. The LA Times referred to oxycodone CR as "a chemical cousin of heroin", but they fail to disclose that dextromethorphan is also "related". Moreover, the opioid reversal agent naloxone is just a single substituent on the tertiary amine (nitrogen) away from oxymorphone, an oxycodone metabolite presumed to be twice the potency of oxycodone. But alas, there is no mention of this by media muckrakers who cherry pick information to get a rise out of readers and politicians. No journalist refers to exenatide as "lizard saliva" or conjugated estrogen as "horse urine". Why? Simply because opioids draw more media buzz. There is no doubt that opioids are overprescribed, but the war on opioids is coming at the expense of millions of patients with chronic pain syndromes requiring opioids.
In conclusion, the evidence is available to support oxycodone CR 12-hour dosing; however, some patients may experience end-of-dose failure with a 12-hour regimen. Allowing every 8-hour dosing for these patients may achieve less oxycodone exposure with the same therapeutic benefit, decrease the need for multiple prescriptions (which may improve compliance and minimize diversion risk), decrease costs, and, most importantly, is just plain common sense. The hoopla and rhetoric employed by media muckrakers in The LA Times and politicians to gain favor among constituents is an attack on Big Pharma without scientific justification to support their claims.

\section{Disclosure}

Jeffrey Fudin is associated with the following: Astra Zeneca (Speakers Bureau, Advisory Board), Clarity (Consultant), DepoMed (Advisory Board, Speakers Bureau), Endo (Consultant, Speakers Bureau), Kaléo (Speakers Bureau, Advisory Board), Kashiv Pharma (Advisory Board), KemPharm (Consultant), Pernix Therapeutics (Speaker), Remitigate, LLC (Owner), and Scilex Pharmaceuticals (Consultant). This article is the sole work of the authors, and stated opinions/ assertions do not reflect the opinion of employers, employee affiliates, and/or pharmaceutical companies listed. It was not prepared as part of the authors duty as federal employees. The authors report no other conflicts of interest in this work.

\section{References}

1. United States Food and Drug Administration. Outpatient Prescription Opioid Utilization in the U.S., Years 2000-2009. July 22, 2010. Available from: http://www.fda.gov/downloads/AdvisoryCommittees/ CommitteesMeetingMaterials/Drugs/AnestheticAndLifeSupportDrugsAdvisoryCommittee/UCM220950.pdf. Accessed July 5, 2016.

2. United States Food and Drug Administration. Risk Evaluation and Mitigation Strategy (REMS) for Extended-Release and Long-Acting Opioids. July 9, 2012. Available from: http://www.fda.gov/Drugs/DrugSafety/ InformationbyDrugClass/ucm163647.htm. Accessed July 5, 2016.

3. Pasternak GW, Pan YX. Mu opioids and their receptors: evolution of a concept. Pharmacol Rev. 2013;65(4):1257-1317.

4. Stamer UM, Bayerer B, Stüber F. Genetics and variability in opioid response. Eur J Pain. 2005;9(2):101-104.

5. MS Contin (morphine sulfate extended-release tablets) package insert Stamford, CT: Purdue Pharma L.P.; 2014.

6. Duragesic (fentanyl transdermal system) package insert. Titusville, NJ Janssen Pharmaceuticals, Inc.; 2014.

7. OxyContin (oxycodone $\mathrm{HCl}$ extended-release) package insert Stamford, CT: Purdue Pharma L.P.; 2015.

8. Ryan H, Girion L, Glover S. 'You want a description of hell?' OxyContin's 12-hour dosing problem. LA Times. May 5, 2016. Available from: http:// www.latimes.com/projects/oxycontin-part1/. Accessed July 4, 2016.

9. Department of Health and Human Services [webpage on the Internet]. Available from: https://www.regulations.gov/contentStreamer? documentId=FDA-2004-P-0294-0051\&attachmentNumber=1\&dispo sition=attachment\&contentType=pdf. Accessed July 27, 2016.

10. Richard Blumenthal Attorney general [webpage on the Internet]. Available from: http://www.fda.gov/ohrms/dockets/dailys/04/ jan04/012804/04p-0043-cp00001-01-vol1.pdf. Accessed July 27, 2016. 
11. FDANEWS [webpage on the Internet]. Available from: http://www. fdanews.com/articles/105468-state-takes-oxycontin-label-disputetocourt?v=preview. Accessed July 27, 2016.

12. Fudin J, Atkinson TJ. Personalized oxycodone dosing: using pharmacogenetic testing and clinical pharmacokinetics to reduce toxicity risk and increase effectiveness. Pain Med. 2014;15(5):723-725.

13. Andreassen TN, Klepstad P, Davies A, Bjordal K, Lundström S, Kaasa $\mathrm{S}$, Dale O. Influences on the pharmacokinetics of oxycodone: a multicentre cross-sectional study in 439 adult cancer patients. Eur J Clin Pharmacol. 2011;67(5):493-506.

14. OxyContin (oxycodone controlled release) archived package insert. Stamford, CT: Purdue Pharma L.P. 2007. Available from: http://www. accessdata.fda.gov/drugsatfda_docs/label/2008/020553s059lbl.pdf

15. Kim DY, Song HS, Ahn JS, Ryoo BY, Shin DB, Yim CY, Kim SY. The dosing frequency of sustained-release opioids and the prevalence of end-of-dose failure in cancer pain control: a Korean multicenter study. Support Care Cancer. 2010;19(2):297-301.

16. Reder RF, Oshlack B, Miotto JB, Benziger DD, Kaiko RF. Steady-state bioavailability of controlled-release oxycodone in normal subjects. Clin Ther. 1996;18(1):95-105.

17. Pattinson KT. Opioids and the control of respiration. Br J Anaesth. 2008;100(6):747-758.

18. Argoff CE, Silvershein DI. A comparison of long- and short-acting opioids for the treatment of chronic noncancer pain: tailoring therapy to meet patient needs. Mayo Clin Proc. 2009;84(7):602-612.
19. Daniell HW. Hypogonadism in men consuming sustained-action oral opioids. J Pain. 2002;3(5):377-384.

20. Rubinstein AL, Carpenter DM, Minkoff JR. Hypogonadism in men with chronic pain linked to the use of long-acting rather than short-acting opioids. Clin J Pain. 2013;29(10):840-845.

21. Kaplan R, Parris WC, Citron ML, Zhukovsky D, Reder RF, Buckley BJ, Kaiko RF. Comparison of controlled-release and immediate-release oxycodone tablets AVINZA and chronic noncancer pain - 263 inpatients with cancer pain. J Clin Oncol. 1998;16(10):3230-3237.

22. Caldwell JR, Hale ME, Boyd RE, Hague JM, Iwan T, Shi M, Lacouture PG. Treatment of osteoarthritis pain with controlled release oxycodone or fixed combination oxycodone plus acetaminophen added to nonsteroidal anti-inflammatory drugs: A double blind, randomized, multicenter, placebo controlled trial. J Rheumatol. 1999;26(4):862-869.

23. Klepsted P, Kaasa S, Jystad A, Hval B, Borchgrevink PC. Immediate or sustained-release morphine for dose finding during start of morphine to cancer patients: A randomized, double-blind trial. Pain. 2003;101(1-2):193-198.

24. McCarberg BH, Barkin RL. Long-acting opioids for chronic pain: pharmacotherapeutic opportunities to enhance compliance, quality of life, and analgesia. Am J Ther. 2001;8(3):181-186.

25. Marcus DA, Glick RM. Sustained-release oxycodone dosing survey of chronic pain patients. Clin J Pain. 2004;20(5):363-366.

26. Weissman DE, Haddox JD. Opioid pseudoaddiction-an iatrogenic syndrome. Pain. 1989;36(3):363-366.

Dove Medical Press encourages responsible, free and frank academic debate. The content of the Journal of Pain Research 'Editorial' section does not necessarily represent the views of Dove Medical Press, its officers, agents, employees, related entities or the Journal of Pain Research editors. While all reasonable steps have been taken to confirm the content of each Editorial, Dove Medical Press accepts no liability in respect of the content of any Editorial, nor is it responsible for the content and accuracy of any Editorial.

Journal of Pain Research

\section{Publish your work in this journal}

The Journal of Pain Research is an international, peer reviewed, open access, online journal that welcomes laboratory and clinical findings in the fields of pain research and the prevention and management of pain. Original research, reviews, symposium reports, hypothesis formation and commentaries are all considered for publication.

\section{Dovepress}

The manuscript management system is completely online and includes a very quick and fair peer-review system, which is all easy to use. Visit http://www.dovepress.com/testimonials.php to read real quotes from published authors. 